\title{
PENGARUH KOMPENSASI DAN MOTIVASI TERHADAP KINERJA ARYAWAN PADA PT. TUNAS JAYA UTAMA
}

\author{
Rini Astuti ${ }^{1)}$, Suhendri ${ }^{2)}$ \\ Fakultas Ekonomi dan Bisnis \\ Universitas Muhammadiyah Sumatera Utara
}

riniastuti@umsu.ac.id

\begin{abstract}
This study aims to determine the effect of compensation on the performance of employees of PT. Jaya Jaya Utama. This study aims to determine the effect of motivation on the performance of PT.Tunas Jaya Utama employees. This study has the aim to determine the effect of compensation and motivation on the performance of PT.Tunas Jaya Utama employees.

The population of this research is 32 employees of PT. Tunas Jaya Utama.

Data collection techniques in this study were interviews, documentary studies and questionnaires, while the data analysis techniques used were the classic assumption test, multiple regression, T test, $\mathrm{F}$ test, and the coefficient of determination.

There is an effect of compensation and motivation on employee performance at PT. Tunas Jaya Utama where the count is 0.349 . The multiple correlation coefficient values together between motivation and workload on performance obtained Rx $1 x 2 y=0.723$. This positive value means that if compensation and motivation are increased the performance will increase. From the $\mathrm{F}$ test it was obtained 15,853 with sig $0,000<0,05$, indicating that Ho was rejected and Ha was accepted, meaning compensation (X1) and motivation (X2) had a significant effect on performance (Y) at the 0.05 level. The coefficient of determination obtained (R-Square) is 0.522 or $52.20 \%$, indicating that around $52.20 \%$ the variable $\mathrm{Y}$ can be explained by the compensation variable (X1) and motivation (X2) or practically it can be said that the contribution of compensation (X1) and motivation (X2) on performance (Y) is $52.20 \%$, the rest is influenced by other variables not examined.
\end{abstract}

Keywords: Compensation, Motivation, Performance 


\section{PENDAHULUAN}

Manusia sebagai salah satu sumber daya yang bersifat dinamis dan memiliki kemampuan untuk terus berkembang perlu mendapat perhatian dari pihak perusahaan. Perhatian ini diperlukan mengingat dalam menjalankan aktivitasnya , perusahaan akan selalu berhadapan dengan sumber daya manusia yang dimilikinya. Dengan demikian pembinaan terhadap sumber daya manusia perlu mendapat perhatian yang besar dalam suatu perusahaan.

Sumber daya manusia sangat penting bagi perusahaan dalam mengelola, mengatur, dan memanfaatkan karyawan sehingga dapat berfungsi secara produktif untuk tercapainya tujuan perusahaan. Sumber daya manusia sebagai penggerak organisasi dalam mencapai tujuan nya, maka upaya - upaya organisasi dalam mendorong karyawan untuk bekerja lebih baik harus terus dilakukan,dengan adanya karyawan - karyawan yang bekerja secara baik ini, maka diharapkan hasil kerja ( kinerja) dalam melaksanakan tugasnya sesuai dengan tanggung jawab yang diberikan kepadanya.

\section{Menurut}

Mangkunegaran (2009:67) kinerja adalah hasil kerja yang dihasilkan oleh seorang karyawan untuk mencapai tujuan yang diharapkan. Kinerja karyawan dalam suatu perusahaan sangatlah penting karena apabila kinerja karyawannya kurang baik, maka dipastikan perusahaan tidak akan mampu bersaing dengan perusahaan lain. Dengan kinerja karyawan yang baik diharapkan perusahaan akan mampu bersaing dengan perusahaan lain. Untuk menciptakan kinerja yang tinggi, dibutuhkan adanya peningkatan kerja yang optimal dan mampu mendayagunakan potensi sumber daya manusia yang dimiliki oleh karyawan guna menciptakan tujuan organisasi, sehingga akan memberikan kontribusi positif bagi perkembangan organisasi.

Penilaian kinerja sangat penting dilakukan untuk melihat seberapa besar kemampuan karyawan dalam melaksanakan pekerjaannya sehari - hari, apakah pekerjaan yang dilakukan sudah sesuai target dan sesuai dengan tujuan dari perusahaan ataukah tidak dapat meningkat sama sekali, selain itu kinerja karyawan secara langsung berpengaruh terhadap citra perusahaan dimata masyarakat luas. Alasan tersebutlah perusahaan harus senantiasa memperhatikan beberapa faktor yang mempengaruhi kinerja karyawannya,seperti kompensasi yang diberikan perusahaan.

Kompensasi sangat penting dalam meningkatkan kinerja karyawan. Pemberian kompensasi yang adil dan tepat diperlukan perusahaan untuk dapat menciptakan kegairahan kerja pada karyawan yang nantinya akan membuat semangat kerja dan pastiya meningkatkan kinerja karyawan itu sendiri. Menurut Malayu S.P.Hasibuan dalam Hazmanan (2017:5) menyatakan bahwa kompensasi adalah semua pendapatan yang bentuk uang, barang langsung atau tidak langsung yang diterima karyawan sebagai imbalan atas jasa yang diberikan kepada perusahaan atau instansi.

Kompensasi financial bermakna imbalan jasa yang diberikan kepada SDM berbentuk uang dan sejenisnya, sedangkan kompensasi non-financial bisa berbentuk kebandaan, fasilitas, jabatan dan lain-lain.

Peningkatan kinerja juga dipengaruhi oleh motivasi kerja karyawan. Menurut Sedarmayanti (2009:65) motivasi merupakan kondisi mental yang mendorong aktivitas dan memberi energy yang mengarah kepada pencapaian kebutuhan. Motivasi merupakan dorongan untuk dapat melakukan suatu aktivitas atau pekerjaan. Motivasi memiliki hubungan yang erat dengan sikap dan perilaku yang dimiliki oleh seseorang. Dengan motivasi kerja yang dapat menambah semangat kerja karyawannya, sehingga kinerja karyawan akan meningkat. Motivasi kerja karyawan dapat timbul dari dalam diri individu dan dari 
luar individu. Motivasi yang timbul dari diri dalam individu misalnya, karyawan yang mempunyai semangat dan inisiatif kerja sendiri dan sadar bahwa karyawan tersebut menunjukkan loyalitas kepada perusahaan. Sedangkan motivasi yang timbul dari luar individu misalnya, adanya faktor lain yang menjadikan dia lebih semangat lagi dalam bekerja. Faktor tersebut bisa datang dari pimpinan, dari rekan kerja, serta pemberian kompensasi yang dapat menumbuhkan semangat karyawan dalam bekerja.

Persaingan yang semakin ketat, mengakibatkan banyak pengusaha yang mendirikan perusahaan khususnya dibidang jasa. Salah satunya adalah PT. Tunas Jaya Utama. Perusahaan tersebut merupakan perusahaan yang bergerak dibidang ekspedisi muatan kapal laut. Dimana PT. Tunas Jaya Utama mengangkut barang dari kapal laut lalu disalurkan pada perusahaan yang telah ditentukan.

PT. Tunas Jaya Utama dalam menjalankan kegiatan perusahaannya mempunyai kendala pada kinerja karyawannya. Hal tersbut ditandai dengan

\section{LANDASAN TEORI}

\section{Kinerja.}

Menurut

Mangkunegaran (2009:67) kinerja adalah hasil kerja yang dihasilkan oleh seorang karyawan untuk mencapai tujuan yang diharapkan.

Menurut Colquitt dalam Kasmir (2015:183) kinerja adalah nilai dari seperangkat perilaku karyawan yang berkontribusi, baik secara positif atau negatif terhadap pemenuhan tujuan organisasi.

Menurut Bangun (2012:231) kinerja (performance) adalah hasil pekerjaan yang dicapai seseorang berdasarkan persyaratan - persyaratan pekerjaan (job requirement).

Berdasarkan pendapat diatas, maka dapat disimpulkan bahwa kinerja merupakan hasil kerja yang dapat tidak tercapainya target atau tujuan perusahaan. Berdasarkan hasil prariset yang dilakukan oleh penulis, hal tersebut disebabkan karena karyawan merasa tidak adil dalam pemberian kompensasi oleh perusahaan. Dimana karyawan dalam mendapatkkan imbal jasa belum sesuai dengan Upah Minimum Regional. Selain itu karyawan tidak mendapatkan bonus serta tunjangan dari perusahaan, seperti yang telah dijanjikan pada saat interview masuk kerja, dimana akan diberikan kompensasi yang sesuai UMR dan diberikan tunjangan. Sehingga hal tersebut dapat menurunkan motivasi karyawan dalam bekerja. Karyawan PT. Tunas Jaya Utama yang sudah lama bekerja juga merasa tidak diberikan penghargaan selama bekerja dan jenjang karirnya juga tidak jelas. Dimana karyawan yang sudah bekerja diatas 5 tahun, hanya menduduki jabatan sebagai staff biasa dan tidak diberi kesempatan untuk naik ke level yang lebih tinggi walaupun mempunyai kinerja yang bagus. Sehingga karyawan PT. Tunas Jaya Utama tidak dapat berkembang.

66

dihasilkan oleh karyawan untuk dapat mencapai tujuan perusahaan.

Faktor-faktor yang mempengaruhi kinerja menurut Mathis dan Jackson dalam Juliansyah (2013) adalah :

1. Kemampuan individual untuk melakukan pekerjaan tersebut,

2. Motivasi

3. Dukungan organisasi.

4. Keberadaan pekerjaan yang dilakukan.

5. Hubungan karyawan dan organisasi.

Menurut Kasmir (2015:196) penilaian kerja memiliki beberapa tujuan antara lain yaitu :

1. Untuk memperbaiki kualitas pekerjaan.

2. Keputusan penempatan. 
3. Perencanaan dan pengembangan karir.

4. Kebutuhan latihan pengembangan.

5. Penyesuaian kompensasi

6. Inventori kompetensi pegawai

7. Kesempatan kerja adil

8. Komunikasi efektif antara atasan bawahan.

9. Budaya kerja.

10. Menerapkan sanksi

Menurut Mangkunegara (2009:

1. Kualitas

75) indikator kerja meliputi :

2. Kuantitas

3. Pelaksanaan tugas

4. Tanggung jawab

\section{Kompensasi}

Menurut William B. Werther dan Keith Davis dalam hazmanan (2017:5) menyatakan bahwa kompensasi adalah apa yang seorang pekerja terima sebagai balasan dari pekerjaan yang diberikan, baik upah per jam ataupun gaji periodik didesain dan dikelola oleh bagian personalia.

Menurut Gary Dessler dalam hazmanan (2017:5) menyatakan bahwa kompensasi adalah setiap bentuk pembayaran atau imbalan yang diberikan kepada karyawan dan timbul dari dipekerjaannya karyawan itu.

Dalam pemberian kompensasi, terdapat sejumlah faktor yang mempengaruhi besaran kompensasi yang akan diterima sumber daya manusia disuatu organisasi atau perusahaan.

Menurut Mangkunegara dalam Hazmanan (2017:8) menguraikan faktorfaktor yang mempengaruhi besar kecilnya kompensasi yang akan diterima individu yang ada di organisasi atau perusahaan.

1) Faktor Pemerintah

2) Penawaran bersama antara perusahaan dan pegawai

3) Standar biaya hidup pegawai

4) Ukuran perbandingan upah

5) Permintaan dan persediaan
Kompensasi mempunyai fungsi yang sangat penting didalam memperlancar jalannya roda organisasi atau perusahaan dan kehidupan suatu negara.

Schunk, Pimtrich \& Meece dalam Hazmanan (2017:104) mengatakan bahwa kompensasi memiliki fungsi pengawasan, dimana semua imbalan memiliki potensi untuk mengawasi dan mengendalikan operasional organisasi.

Sedangkan Komaruddin dalam Hazmanan (2017:103) mendeskripsikan fungsi kompensasi berupa gaji yang dapat membantu manajer personalia dalam:

1) Menarik pekerja yang mempunyai kemampuan ke dalam organisasi.

2) Mendorong pekerja agar menunjukkan prestasi yang tinggi.

3) Memelihara prestasi pekerja selama periode yang panjang.

Secara umum tujuan dari manajemen kempensasi adalah untuk membantu organisasi mencapai keberhasilan strategis dan menjamin terciptanya keadilan internal dan eksternal.

Menurut Werther dan Davis dalam hazmanan (2017:105) menyatakan bahwa pemberian kompensasi bertujuan untuk :

1) Memperoleh personel berkualitas Kompensasi perlu ditetapkan cukup tinggi untuk mampu menarik jumlah pelamar.

2) Mempertahankan karyawan yang ada Pekerja dapat keluar apabila tingkat kompensasi tidak kompetitif terhadap organisasi lain yang berkibat kepada perputaran tenaga kerja tinggi.

3) Memastikan Keadilan

Manajemen kompensasi berusaha keras menjaga keadilan internal dan eksternal.

4) Menghargai perilaku yang diinginkan Pembayaran harus memperkuat perilaku yang diinginkan dan bertindak sebagai insentif untuk perilaku di masa depan, rencana kompensasi yang efektif menghargai 
kinerja, loyalitas, keahlian dan tanggung jawab.

Menurut Simamora pada

Darodjat dalam Hazmanan (2017:191)

menguraikan bahwa indikator kompensasi

sebagai berikut :

1) Arti penting, sebuah imbalan tidak bakal dapat mempengaruhi apa yang dilakukan oleh orang-orang atau bagaimana perasaan mereka jika hal tersebut tidak penting bagi mereka.

2) Fleksibilitas, jika sistem imbalan disesuaikan dengan karakteristikkarakteristik unik dari individu, dan jikam imbalan disediakan tergantung pada tingkat kinerja tertentu.

3) Frekuensi, semakin sering suatu imbalan dapat diberikan, semakin besar potensi daya gunanya sebagai alat yang mempengaruhi kinerja karyawan.

4) Visibilitas, imbalan-imbalan yang dapat dilihat jika dikehendaki supaya kalangan karyawan merasakan danya hubungan antara kinerja dan imbalanimbalan.

5) Biaya, sistem kompensasi nyata sekali tidak dapat dirancang tanpa pertimbangan yang diberikan terhadap biaya imbalan-imbalan yang tercakup.

\section{Motivasi}

Menurut Sedarmayanti (2009:65) motivasi merupakan kondisi mental yang mendorong aktivitas dan memberi energy yang mengarah kepada pencapaian kebutuhan.

Menurut Newstrom dalam Juliansyah (2013:227) motivasi adalah kesediaan individu untuk mengeluarkan upaya yang tinggi untuk mencapai tujuan organisasi. Motivasi sebagai suatu kondisi yang menggerakkan manusia ke arah suatu tujuan tertentu.

Menurut Kreitner dan Kinicki dalam Juliansyah (2013:226) motivasi berarti suatu kondisi yang menggerakkan atau menjadi sebab seseorang melakukan suatu perbuatan / kegiatan, yang berlangsung secara sadar, juga sebagai suatu kekuatan sumber daya yang menggerakkan dan mengendalikan perilaku manusia.

Menurut Sutrisno (2015:116) motivasi sebagai proses psikologis dalam diri seseorang akan dipengaruhi oleh beberapa faktor. Faktor -faktor tersebut dapat dibedakan atas faktor intern dan ektern yang berasal dari karyawan.

1. Faktor Intern Faktor Intern yang dapat memengaruhi pemberian motivasi pada seseorang antara lain:

a) Keinginan untuk dapat hidup

b) Keinginan untuk dapat memiliki

c) Keinginan untuk memperoleh penghargaan.

d) Keinginan untuk memperoleh pengakuan.

e) Keinginan untuk berkuasa.

2. Faktor ekstern

Faktor ekstern juga tidak kalah peranannya dalam melemahkan motivasi kerja seseorang. Faktor faktor ekstern itu adalah :

a) Kondisi lingkungan kerja.

b) Kompensasi yang memadai.

c) Supervisi yang baik.

d) Adanya jaminan pekerjaan.

e) Status dan tanggung jawab.

f) Peraturan yang fleksibel.

Menurut Hasibuan (2007:146)

tujuan motivasi antara lain sebagai

berikut:

1. Meningkatkan moral dan kepuasan kerja karyawan.

2. Meningkatkan produktifitas kerja karyawan.

3. Mempertahankan kestabilan karyawan perusahaan.

4. Meningkatkan kedisiplinan karyawan.

5. Mengefektifkan pengadaan karyawan.

6. Menciptakan suasana dan hubungan kerja yang baik.

7. Meningkatkan loyalitas, kreatifitas dan partisipasi karyawan.

8. Meningkatkan tingkat kesejahteraan karyawan. 
9. Mempertinggi rasa tanggung jawab karyawan terhadap tugas- tugasnya.

10. Meningkatkan efisiensi penggunaan alat - alat dan bahan baku.

Indikator - indikator untuk

mengukur motivasi kerja menurut

Syahyuti (2010) adalah:

1. Dorongan mencapai tujuan

2. Semangat kerja.

3. Inisiatif dan kreatifitas.

4. Rasa tanggung jawab.

\section{METODOLOGI PENELITIAN}

Pendekatan penelitian yang dilakukan oleh peneliti adalah dengan menggunakan pendekatan asosiatif dan kuantitatif. Dalam penelitian ini, tempat penelitian adalah di PT. Tunas Jaya Utama di Jln. Belibis No.8F Kel. Sampali (20371) Medan - Sumut. Waktu penelitian yang dilaksanakan mulai dari bulan November 2017 sampai dengan Maret 2018. Dalam hal ini yang menjadi populasinya adalah karyawan PT. Tunas

\section{HASIL PENELITIAN DAN PEMBAHASAN}

\section{Uji Normalitas}

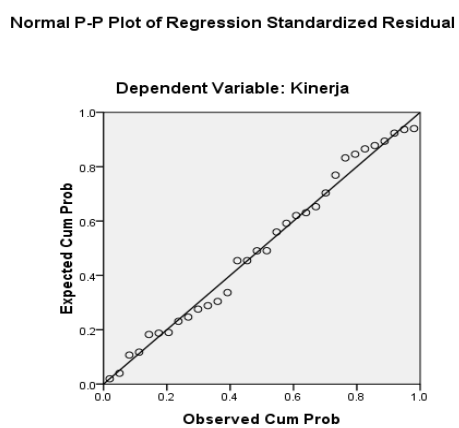

Gambar 1. Normalitas

Gambar diatas mengidentifikasi bahwa model regresi telah memenuhi asumsi yang telah dikemukakan sebelumya, sehingga data dalam model regresi penelitian cenderung normal.
Jaya Utama yaitu 32 orang. Pengambilan sampel, penulis menggunakan jenis Nonprobability sampling. Dengan menggunakan teknik Sampling jenuh yaitu teknik penentuan sampel bila semua anggota populasi digunakan sebagai sampel. Sehingga sampel dalam penelitian ini berjumlah 32 orang. Untuk memperoleh data yang lengkap dan teliti dalam penelitian, teknik pengumpulan data yang digunakan adalah; Studi dokumentasi, Wawancara (Interview), Daftar Pertanyaan (quesioner) yang diujui menggunkan Uji Validitas, Uji Reliabilitas. Teknik analisis yang digunakan dalam penelitian ini adalah analisis data penelitian asosiatif. menggunakan rumus analisis regresi linear berganda. Hipotesis memerlukan uji asumsi klasik, terdiri dari: Uji Normalitas Data, Uji Multikolineritas, Uji Heteroskedastisitas. Pengujian Hipotesis menggunakan rumus: Uji T, dan Uji F dan Koefisien Determinasi.

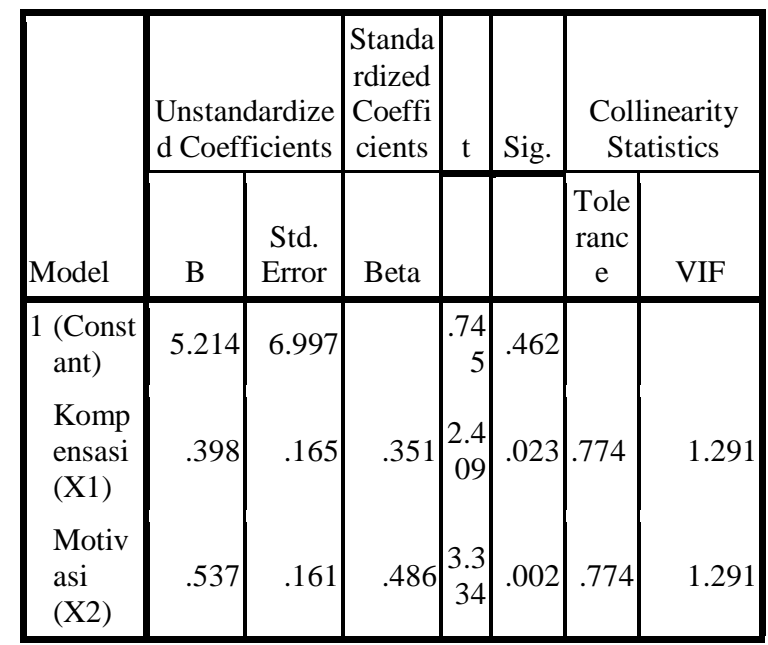

Kedua variabel independen yakni X1 dan X2 memiliki nilai VIF dalam batas toleransi yang telah ditentukan (tidak melebihi 4 atau 5), sehingga tidak menjadi multikolinearitas dalam variabel independen penelitian ini.

\section{Mulitikolinearitas}

Tabel 1. Uji Multikolinearitas

Coefficients $^{a}$ 


\section{Heterokedastisitas}

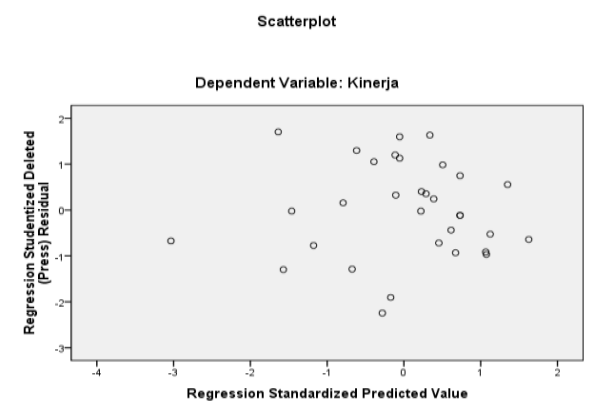

Gambar 2. Heterokedastisitas

Gambar diatas memperlihatkan titik-titik menyebar secara acak, tidak membentuk pola yang jelas / teratur, serta tersebar baik diatas maupun dibawah angka 0 pada sumbu $\mathrm{Y}$ dengan demikian "tidak terjadi heterokedastisitas" pada model regresi.

\section{Regresi Linier Berganda}

Persamaan regresi berganda dapat dilihat dari nilai koefisien B pada tabel berikut ini

Tabel 2. Koefisien Regresi

\section{Coefficients $^{a}$}

\begin{tabular}{|l|r|r|r|r|r|}
\hline & \multicolumn{2}{|c|}{$\begin{array}{c}\text { Standard } \\
\text { ized } \\
\text { Unstandardize } \\
\text { Coeffici } \\
\text { ents }\end{array}$} & t & Sig. \\
\cline { 2 - 6 } Model Coefficients & \multicolumn{1}{|c|}{ B } & $\begin{array}{c}\text { Std. } \\
\text { Error }\end{array}$ & Beta & & \\
\hline 1 (Constant) & 5.214 & 6.997 & & .745 & .462 \\
$\begin{array}{l}\text { Kompensasi } \\
\text { (X1) }\end{array}$ & .398 & .165 & .351 & 2.40 & .023 \\
$\begin{array}{l}\text { Motivasi } \\
\text { (X2) }\end{array}$ & .537 & .161 & .486 & 3.33 & .002 \\
\hline
\end{tabular}

Dari perhitungan dengan menggunakan program komputer dengan menggunakan SPSS (Statistical Program For Social Schedule) versi 16.0 di dapat:

$$
\begin{aligned}
& \mathrm{a}=5,214 \\
& \mathrm{~b} 1=0,398 \\
& \mathrm{~b} 2=0,537
\end{aligned}
$$

Jadi persamaan regresi ganda linier untuk dua prediktor (motivasi dan beban kerja) adalah:

$$
Y=5,214+0,398 X_{1}+0,537 X 2
$$

Persamaan diatas memperlihatkan bahwa semua variabel bebas (kompensasi dan motivasi) memiliki koefisien bi yang positif, berarti seluruh variabel bebas mempunyai hubungan yang searah terhadap variabel Y (kinerja). Variabel kompensasi (X1) memiliki kontribusi relatif yang paling besar di antara kedua variabel bebas.

\section{Pengujian Secara Parsial (Uji T)}

Penguji hubungan variabelvariabel bebas $(\mathrm{X})$ terhadap variabel terikat (Y) dapat dilihat pada tabel berikut ini :

Tabel 3. Uji Parsial (Uji t)

\section{Coefficients}

\begin{tabular}{|c|c|c|c|c|c|}
\hline & \multicolumn{2}{|c|}{$\begin{array}{c}\text { Unstandardize } \\
\text { d Coefficients }\end{array}$} & $\begin{array}{c}\text { Standar } \\
\text { dized } \\
\text { Coeffic } \\
\text { ients }\end{array}$ & $\mathrm{t}$ & Sig. \\
\cline { 2 - 6 } Model & $\mathrm{B}$ & $\begin{array}{c}\text { Std. } \\
\text { Error }\end{array}$ & Beta & & \\
\hline $\begin{array}{c}\text { 1(Cons } \\
\text { ant) }\end{array}$ & 5.214 & 6.997 & & .745 & .462 \\
$\begin{array}{c}\text { Komp } \\
\text { ensasi } \\
(\mathrm{X} 1)\end{array}$ & .398 & .165 & .351 & 2.409 & .023 \\
$\begin{array}{c}\text { Motiv } \\
\text { asi } \\
\text { (X2) }\end{array}$ & .537 & .161 & .486 & 3.334 & .002 \\
\hline
\end{tabular}

1) Pengaruh Kompensasi Terhadap Kinerja Berdasarkan data tabel uji $t$ di atas dapat diketahui bahwa perolehan nilai coefficients: $\mathrm{t}_{\text {hitung }}=2,409 \mathrm{t}_{\text {tabel }}=2,042$

Berdasarkan hasil pengujian di atas variabel Kompensasi (X1) diperoleh thitung sebesar 2,409 dengan nilai signifikan 0,023 sedangkan nilai ketentuan untuk 32 sample ttabel sebesar 2,042 dengan nilai signifikan 0,05 . Kesimpulannya thitung $2,409>$ ttabel 2,042 dengan nilai signifikan $0,023<0,05$ maka Ho ditolak dan Ha diterima yang berarti bahwa secara parsial kompensasi (X1) berpengaruh signifikan terhadap kinerja (Y) pada PT.Tunas Jaya Utama.

2) Pengaruh Motivasi Terhadap Kinerja

Berdasarkan data tabel uji $t$ di atas dapat diketahui bahwa perolehan nilai coefficients: $\mathrm{t}_{\text {hitung }}=3,334 \mathrm{t}_{\text {tabel }}=2,042$

Motivasi (X2) diperoleh thitung sebesar 3,334 dengan nilai signifikan 0,002 sedangkan nilai ketentuan untuk 32 sample ttabel sebesar 2,042 dengan nilai signifikan 0,05 . Kesimpulannya thitung 3,334 > ttabel 
2,042 dengan nilai signifikan 0,002 $<0,05$ maka Ho ditolak dan $\mathrm{Ha}$ diterima yang berarti bahwa secara parsial motivasi (X2) berpengaruh signifikan terhadap kinerja (Y) pada PT.Tunas Jaya Utama.

\section{Uji F}

Tabel 4. Uji Simultan (Uji F)

\begin{tabular}{|c|c|c|c|c|c|}
\hline Model & $\begin{array}{l}\text { Sum of } \\
\text { Squares }\end{array}$ & Df & $\begin{array}{c}\text { Mean } \\
\text { Square }\end{array}$ & $\mathrm{F}$ & Sig. \\
\hline $\begin{array}{l}1 \text { Regre } \\
\text { ssion }\end{array}$ & 175.470 & 2 & 87.735 & $\begin{array}{r}15.8 \\
53\end{array}$ & $.000^{\circ}$ \\
\hline $\begin{array}{l}\text { Resid } \\
\text { ual }\end{array}$ & 160.498 & 29 & 5.534 & & \\
\hline Total & 335.969 & 31 & & & \\
\hline
\end{tabular}

Berdasarkan data tabel uji $\mathrm{F}$ diperoleh nilai Fhitung sebesar 15,853 dengan nilai signifikan 0,000 pada Ftabel untuk 32 sample dengan signifikan 0,05 dengan nilai Ftabel sebesar 3,34, maka diperoleh Fhitung 15,853 > Ftabel 3,34 dengan nilai signifikan 0,000 dibawah nilai 0,05 yang menunjukkan bahwa variabel kompensasi (X1), dan motivasi (X2) secara simultan berpengaruh terhadap kinerja (Y) pada PT.Tunas Jaya Utama.

\section{a. Koefisien Determinasi (R-Square)}

Selanjutnya dengan melihat $R$-Square akan dapat dilihat bagaimana sebenarnya nilai kontribusi kedua variabel bebas terhadap variabel terikat :

Tabel 5. Koefisien Determinasi Model Summary ${ }^{\mathrm{b}}$

\begin{tabular}{|l|c|r|r|r|}
\hline Model & $\mathrm{R}$ & $\begin{array}{c}\mathrm{R} \\
\text { Square }\end{array}$ & $\begin{array}{c}\text { Adjusted R R } \\
\text { Square }\end{array}$ & $\begin{array}{c}\text { Std. Error } \\
\text { of the } \\
\text { Estimate }\end{array}$ \\
\hline 1 & $.723^{\mathrm{a}}$ & .522 & .489 & 2.35254 \\
\hline
\end{tabular}

Dari tabel $5 \mathrm{di}$ atas terlihat bahwa nilai $\mathrm{R}$ adalah 0,723 dan R-Square adalah 0,522 atau 52,20\%. Dari nilai R-Square dapat diketahui bahwa secara bersama motivasi dan beban kerja memiliki pengaruh sebesar $52,2 \%$, sedangkan sisanya sebesar $47,8 \%$ dipengaruhi oleh faktor lain diluar penelitian ini.

\section{PEMBAHASAN}

Dari hasil penelitian terlihat bahwa semua variabel bebas (kompensasi dan motivasi) memiliki koefisien $b$ yang positif, berarti seluruh variabel bebas mempunyai pengaruh yang searah terhadap variabel $\mathrm{Y}$ (Kinerja). Lebih rinci hasil analisis dan pengujian tersebut dapat dijelaskan sebagai berikut :

\section{Pengaruh Kompensasi terhadap Kinerja}

Dari hasil uji statistik Kompensasi (X1) berpengaruh positif dan signifikan terhadap kinerja (Y) pada PT. Tunas Jaya Utama. Dikarenakan hasil thitung 2,409 > ttabel 2,042 dengan nilai signifikan 0,023 < 0,05 maka Ho ditolak dan Ha diterima.

Hasil penelitian ini sejalan dengan penelitian sebelumnya yang dilakukan oleh Yahyo (2013) bahwa kompensasi memiliki pengaruh yang positif terhadap kinerja karyawan.

Hasil penelitian ini sesuai dengan teori yang dikemukakan oleh Kasmir (2016) dimana karyawan yang memiliki kinerja yang baik tentu akan memperoleh balas jasa, misalnya kenaikan gaji ataupun tunjangan lainnya. Sehingga kinerja akan memengaruhi kompensasi karyawan pada suatu perusahaan.

\section{Pengaruh Motivasi terhadap Kinerja}

Dari hasil uji statistik Motivasi (X2) berpengaruh positif dan signifikan terhadap kinerja (Y) pada PT. Tunas Jaya Utama. Dikarenakan hasil thitung 3,334> tabel 2,042 dengan nilai signifikan $0,002<0,05$ maka Ho ditolak dan Ha diterima.

Hasil Penelitian ini sejalan dengan peneliti sebelumnya yang dilakukan oleh Yahyo (2013) bahwa motivasi memiliki pengaruh positif terhadap kinerja karyawan. Dimana motivasi memiliki dampak terhadap kinerja, apabila motivasi baik maka kinerja karyawan akan meningkat, dan sebaliknya.

Hasil penelitian ini sesuai dengan teori yang dikemukakan oleh Juliansyah (2013: 280) juga menyatakan bila motivasi kerja seorang rendah, maka kinerjanya akan rendah pula meskipun kemampuannya ada dan baik, serta peluangnya tersedia. 
Motivasi kerja seseorang besar tetapi peluang untuk memanfaatkan kemampuan kemampuannya tidak ada, maka kinerjanya menjadi rendah. Begitu pula bila motivasi kerjanya besar, kesempatan tersedia , tetapi kemampuan dan keahlian tidak ditingkatkan, maka kinerjanya juga rendah.

\section{Pengaruh Kompensasi dan Motivasi terhadap Kinerja}

Pengujian yang dilakukan secara simultan menunjukkan bahwa variabel Kompensasi (X1), dan Motivasi (X2) berpengaruh signifikan terhadap Kinerja (Y) pada PT.Tunas Jaya Utama. Dikarenakan hasil Fhitung 15,853 > Ftabel 3,34 dengan nilai signifikan 0,05 maka Ho ditolak dan Ha diterima.

Dengan nilai R Square sebesar 0,522 atau $52,2 \%$ yang berarti bahwa hubungan antara Kinerja (Y) dengan Kompensasi

\section{Saran}

Dari hasil penelitian ini dapat diajukan beberapa saran sebagai berikut :

1. Saran Praktis

a.Bagi Pada PT. Tunas Jaya Utama hendaknya hasil penelitian ini dijadikan pertimbangan untuk meningkatkan kinerja karyawan. Hasil penelitian ini menunjukkan nilai yang positif, yang berarti jika kompensasi dan motivasi ditingkatkan maka kinerja juga meningkat, sehingga ada baiknya pimpinan selalu memberikan kompensasi dengan baik dan meningkatkan motivasi.

2. Saran Teoritis

a.Disarankan bagi peneliti lain agar dapat menjadi pedoman/acuan untuk melakukan penelitian lebih mendalam terhadap kontribusi dari variabel kompensasi dan motivasi terhadap kinerja.

b. Disarankan bagi peneliti selanjutnya agar dapat melakukan penelitian dengan melihat korelasi dari faktorfaktor yang mempengaruhi kinerja karyawan.
(X1), dan Motivasi (X2) adalah rendah, sedangkan sisanya $47,8 \%$ variabel-variabel lain yang tidak diteliti oleh penelitian ini.

\section{Kesimpulan}

Berdasarkan data yang diperoleh dalam penelitian mengenai Pengaruh Kompensasi dan Motivasi Terhadap Kinerja Karyawn Pada PT. Tunas Jaya Utama. Responden pada penelitian ini berjumlah 32 karyawan, kemudian telah dianalisa, maka kesimpulan sebagai berikut :

1. Terdapat pengaruh signifikan dan positif variabel kompensasi terhadap variabel kinerja

2. Terdapat pengaruh signifikan dan positif variabel motivasi terhadap variabel kinerja

3. Kompensasi dan Motivasi keduanya sangat mempengaruhi kinerja karyawan

\section{DAFTAR PUSTAKA}

Among Makarti (2016) "Pengaruh Motivasi dan Budaya Organisasi terhadap Kepuasan Kerja serta Implikasinya terhadap Kinerja Karyawan pada Rumah Sakit Umum Salatiga". STIE AMA Salatiga. Vol. 9 No.17, Juli 2016.

Arianti,dkk (2016) “Manajemen Sumber Daya Manusia" Medan, Perdana Publishing.

Bangun, Wilson (2012) "Manajemen Sumber Daya Manusia" Bandung, Penerbit Erlangga.

Febri Furqon Artadi (2015) Pengaruh Kepuasan Kerja dan Beban Kerja terhadap Kinerja Karyawan Pada PT. Merapi Agung Lestari. Fakultas Ekonomi Universitas Negeri Yogyakarta. Skripsi S1. Tidak Dipublikasikan.

Iga Mawarni Marpaung (2014) "Pengaruh Motivasi dan Disiplin Kerja terhadap Kinerja Karyawan $R S$. Reksa Waluyo Mojokerto" Fakultas Ilmu Administrasi Universitas Brawijaya. Vol. 15 No.2, Oktober 2014. 
Ikhsan, Arfan,dkk (2014) "Metodologi Penelitian Bisnis" Bandung, Citapustaka Media.

Juliandi,dkk (2015) "Metodologi penelitian Bisnis" Medan, Umsu Press.

Kasmir. (2015) "Manajemen Sumber Daya Manusia" Jakarta, PT. Raja Grafindo Persada.

Kaswan. (2012) "Manajemen Sumber Daya Manusia untuk Keunggulan Bersaing Organisasi" Yogyakarta, Graha Ilmu.

Nurdin (2012) “ Pengaruh Motivasi Kerja dan Besarnya Gaji terhadap Kinerja Karyawan di PT. Citra Rahayu Abadi" STIE Sailendra. Vol. 3 No.3, September 2012.

Nurhayana (2014) "Pengaruh Beban Kerja dan Pelatihan Melalui Motivasi Sebagai Variabel Mediasi terhadap Kinerja Perawat Ruang Rawat Inap RSUD Puri Husada di Tembilahan" Fakultas Ekonomi Universitas Riau Vol. 4 No. 3, September 2014.
Pilatus Deikme (2013) "Motivasi Kerja dan Budaya Organisasi Pengaruhnya terhadap Kinerja Pegawai Bagian Keuangan Sekda Kabupaten Mimika Provinsi Papua" Fakultas Ekonomi Universitas Sam Ratulangi. Vol. 1 No.3, Juni 2013

Pujiyanti (2012) Pengaruh Motivasi Kerja dan Disiplin Kerja terhadap Kinerja Guru di SMA NEGERI 1 Ciamis. Fakultas Ekonomi Universitas Negeri Yogyakarta. Skripsi s1. Tidak Dipublikasikan

Sarly Sariadi (2013) “Gaya Kepemimpinan dan Motivasi Pengaruhnya terhadap Kinerja Pegawai Pada Bagian Seketariat TNI AL LANTANAL VIII di MANADO" Fakultas Ekonomi dan Bisnis Universitas Sam Ratulangi Manado. Vol. 1 No.4, Desember 2013.

Sugiyono (2016) "Metode Penelitian Kuantitatif, Kualitatif, dan RD" Bandung, CV. Alfabeta. 